\title{
Voces femeninas en To the Lighthouse de Virginia Woolf
}

\author{
Marina FE \\ Universidad Nacional Autónoma de México
}

El lenguaje lineal difícilmente puede dar cuenta de los procesos de conciencia que tienen lugar no solamente en un instante sino también, con mucha frecuencia, simultáneamente. ¿Cómo escribir lo que pasa por la mente de una persona en un momento, lo que piensan distintas personas en ese mismo momento? Probablemente debido a esta dificultad práctica se debe en parte el procedimiento técnico al que recurre Virginia Woolf para crear a sus personajes, los cuales no aparecen nunca como seres de una sola pieza sino más bien como fragmentados, con diferentes facetas, como rompecabezas que se van armando poco a poco hasta lograr una cierta densidad, aunque no necesariamente una definición.

En To the Lighthouse, el tiempo del relato, el tiempo diegético, ocupa un segundo plano: es el tiempo exterior que contrasta con el tiempo interno de los personajes y que parece detenerse para ceder su lugar a ese tiempo del pensamiento, del monólogo interior: "How then did it work out, all this? How did one judge people, think of them? How did one add up this and that and conclude that it was liking one felt, or disliking? And to those words, what meaning attached, after all?" (40).

Esto se lo pregunta la pintora Lily Briscoe, invitada por los Ramsey a su casa veraniega, cuando inmediatamente después irrumpe la voz narradora que parece tomar el relevo sin interrumpir esa misma reflexión, como si pretendiera comunicar al lector la dificultad de expresar, con la precaria herramienta de la escritura, esas impresiones, esas ideas que surgen espontáneamente:

Standing now, apparently transfixed, by the pear tree, impressions poured in upon her of these two men, and to follow her thought was like following a voice which speaks too quickly to be taken down by one's pencil, and the voice was her own voice saying without prompting undeniable, everlasting, contradictory things, so that even 
the fissures and humps on the bark of the pear tree were irrevocably fixed there for eternity (40).

La voz narradora se confunde así con las voces interiores de los personajes, con su conciencia, sin ninguna autoridad ni omnisciencia, procurando aparecer más bien como una voz mediadora que no afirma nada sino que es sólo una más en un conjunto de voces que se mezclan y llegan incluso a entretejerse y confundirse en este texto donde "nadie sabe exactamente lo que ocurre: todo son barruntos, ojeadas que alguien lanza sobre otra persona, sin poder descifrar su enigma" (Auerbach: 501). Este mismo procedimiento es utilizado a lo largo de la novela no solamente para entrar en la mente de diferentes personajes en términos individuales sino también, en ocasiones, para mostrar lo que tiene lugar en la conciencia de diferentes personajes al mismo tiempo, casi simultáneamente, como si se tratara de un coro de voces silenciosas.

En el capítulo XVII de la primera parte, durante la cena, descubrimos esa especie de sinfonía en todo su esplendor:

"But what have I done with my life? Thought Mrs. Ramsey... (125) [mientras disponía los lugares de sus invitados y empezaba a servirles la sopa]. They all sat separate. And the whole of the effort of merging and flowing and creating rested on her. Again she felt, as a fact without hostility, the sterility of men, for if she did not do it, nobody would do it..." (126). [Pero enseguida leemos lo que piensa Lily, que la observa y se dice, entre otras cosas]: "How old she looks, how worn she looks [...] and how remote" (127). [Para después pensar en los otros, y en sí misma y en su trabajo]: "Yes, I shall put the tree further in the middle; then I shall avoid that awkward space..." (128) [y así sucesivamente, siguiendo con Charles Tansley que le había dicho a Lily que las mujeres no podían pintar ni escribir, hasta incluir una especie de conciencia colectiva]: "for the night was now shut off by panes of glass, which, far from giving any accurate view of the outside world, rippled it so strangely that there, inside the room, seemed to be order and dry land; there, outside, a reflection in which things wavered and vanished, waterily. [...] and they were all conscious of making a party together, in a hollow, on an island; had their common cause against that fluidity out there" (147).

En este momento privilegiado de unificación, la conciencia interior parecería ser una sola (de ahí la necesidad de que sea la voz narradora la que dé cuenta de lo que está sucediendo), para dar lugar a un orden en lo que de otra manera sería, si no el desorden, sí un conjunto de voces inco- 
nexas: "Woolf uses free indirect discourse throughout the novel in a manner which often makes it difficult to decide who is speaking. Individual subjectivity dissolves into a verbal intersubjectivity" (Waugh: 108).

Quiero hacer énfasis aquí en la noción de interioridad. A lo largo de la novela queda claro que la importancia que Virginia Woolf le da a la conciencia interior de sus personajes no es sólo por el mero gusto experimental o por el reto que representa la utilización de un recurso técnico de esta naturaleza, sino que se trata de un elemento necesario en su obra. Hay dos tipos de experiencias del mundo, dos formas distintas de vivir la vida, parecería querer mostrar Woolf: una exterior y otra interior. La primera está ligada al lenguaje ordinario y a lo que éste es capaz de decir; mientras que la segunda se remite aquellas impresiones, sensaciones, emociones o ideas subjetivas, íntimas, que resultan casi imposibles de expresar. Se trata de experiencias excepcionales y por lo mismo pasajeras, como la vida misma. Esto lo sabe muy bien Mrs. Ramsey quien:

\begin{abstract}
With her foot on the threshold she waited a moment longer in a scene which was vanishing even as she looked, and then, as she moved and took Minta's arm and left the room, it changed, it shaped itself differently; it had become, she knew, giving one last look to it over her shoulder, already the past (168).
\end{abstract}

Aquí, aunque se trata de un monólogo narrado en tercera persona, leemos desde el punto de vista de Mrs. Ramsey y conocemos sus sensaciones y pensamientos.

Virginia Woolf busca penetrar esta interioridad de sus personajes para "decir la vida" subjetiva, desde adentro. Pero en esta novela, como en otras tantas, Woolf privilegia la perspectiva femenina: conocemos más que a nadie a Mrs. Ramsey y a Lily Briscoe, quien la observa con una mirada solidaria y al mismo tiempo crítica. Esta relación entre ambas mujeres es sin duda el centro de To the Lighthouse. Lily, en su pintura, se esfuerza por expresar esa misma experiencia subjetiva en un lenguaje que logre abrir una brecha o tender un puente con el mundo de los otros, y especialmente con Mrs. Ramsey. A diferencia de ésta, que es una mujer de extraordinaria belleza, con una vida muy activa y con un vigor vital que parece ligarla indisolublemente al presente inmediato y a todos los que necesitan de ella (sus hijos, su esposo, sus amigos, los pobres), Lily busca detener el instante, apresar la belleza, lograr que su voz trascienda. Mrs. Ramsey, por otra parte, no parece tener mucho que decir: "there was nothing to be said... she often felt she was nothing but a sponge full 
of human emotions..." y también, "So boasting of her capacity to surround and protect, there was scarcely a shell of herself left for her to know herself by; all was so lavished and spent..." (60). Su creatividad parece radicar exclusivamente en su capacidad de ser para los otros, en una subjetividad basada en las relaciones afectivas.

Aquí es importante tener presente el feminismo de Virginia Woolf y su crítica constante al patriarcado y a una cultura que promueve al individuo autónomo y racional. Como en muchas de sus novelas, en ésta Woolf establece una tensión entre los géneros. De cierta manera, Mrs. Ramsey representa al "Angel in the House" que Virginia dice que hay que matar, pero también es la depositaria de una serie de virtudes "femeninas" como la capacidad de establecer y fortalecer las relaciones afectivas, la atención y el cuidado de los otros. Dicha tensión es fundamental en To the Lighthouse, este künstlerromane que presenta a Lily, la artista, enfrentando el problema de su propia creatividad a partir de su relación con los Ramsey. Desde esta perspectiva y de acuerdo con Rachel Blau du Plessis:

Lily's painting... a vivid formulation of the novel's themes in an imaginary plastic structure, is "about" a mother and child, Mrs. Ramsey and James, or Lily herself, poised between strong opposing forces representing male and female -Mr. And Mrs. Ramsey. The creation of that dynamic poise has been the central aesthetic struggle for Lily (94-95).

Pero Lily tiene serios problemas: no puede identificarse con Mrs. Ramsey, aunque encuentre en ella la personificación de cualidades como la intuición, la entrega a los demás, el cariño y la protección; y es que, al mismo tiempo, ve en ella a una mujer cuya femineidad, construida de acuerdo con los términos de una sociedad patriarcal, le impide tener una identidad definida, independiente:

Mrs. Ramsey is clearly not the focus of a simple affirmation of aesthetic vision but the object of a critical gaze, largely represented through the ambivalent perspective of Lily as a woman (as well as an artist) who sees the pernicious implications of Mrs. Ramsey's selfpresentation in these terms (Waugh: 108).

En la medida en que Mrs. Ramsey es el objeto de su pintura, Lily no sabe exactamente qué está buscando expresar, o cómo hacerlo de una manera auténtica, a partir de su propia experiencia de vida y más allá de la abstracción conceptual: 
She could not show him what she wished to make of it, could not see it even herself, without a brush in her hand. She took up once more her old painting position with the dim eyes and the absent-minded manner, subduing all her impressions as a woman to something much more general: becoming once more under the power of that vision which she had seen clearly once and must now grope for among hedges and houses and mothers and children - her picture (82).

En la primera parte de la novela, "The Window", Lily no consigue terminar su pintura porque sigue siendo incapaz de reconciliar su experiencia femenina con las demandas masculinas de expresión artística (problema en el que en muchos otros de sus textos Virginia Woolf insistió, explicando que las escritoras tenían que encontrar lo que llamaba "a woman's sentence", "the psychological sentence of the femenine gender"). No puede dejar de pensar en el trabajo filosófico de Mr. Ramsey ("Subject and object and the nature of reality") y en la proposición que resume sus planteamientos: "Think of a table... 'when you are not there' [...] And with a painful effort of concentration, she focused her mind, not upon the silver-bossed bark of the tree, or upon its fish-shaped leaves, but upon a phantom kitchen table..." (38).

Este esfuerzo de abstracción plantea, en cierto sentido, la actitud estética e intelectual masculina que Mr. Ramsey representa: "Mr. Ramsey is a system builder, struggling in vain to reach the elusive letter in the linear alphabet of knowledge - the $\mathrm{R}$, which he cannot grasp without accepting the personal and the subjective" (Blau du Plessis: 95). Por otra parte, en esta misma reflexión de Lily, Virginia Woolf muestra su fina ironía en relación con la actitud masculina:

Naturally, if one's days were passed in this seeing of angular essences, this reducing of lovely evenings, with all their flamingo clouds and blue and silver to a white deal four-legged table (and it was a mark of the finest minds so to do), naturally one could not be judged like an ordinary person (38).

Al contrario, Lily busca, mediante la creación artística, dar cuenta de su propia experiencia, de sus "impresiones como mujer", pero no alcanza a lograrlo ("and Mr. Tansley whispering in her ear, 'Women can't paint, women can't write'"...) ya que ella, como la propia Woolf, considera el arte desde una perspectiva vivencial, relacionándolo con el mundo y con la vida: "an exploration of the place of the aesthetic in all fundamental human experience: love, mourning, loss, death. Lily probes issues about 
art and representation as existencial and not simply aesthetic problems" (Waugh: 111).

No puede terminar su pintura en esta primera parte de la novela porque todavía no ha logrado una síntesis justamente entre su concepción formal y abstracta del arte y su apreciación subjetiva, emocional y vital.

En la segunda parte de la novela, "Time Passes", en la casa abandonada y polvorienta ("Think of a table... when you are not there"), en la profusión de oscuridad y el deterioro del paso del tiempo, descubrimos por un paréntesis que Mrs. Ramsey ha muerto y que su muerte ha traído consigo una especie de caos, de falta de armonía. Sólo parece quedar, como un recordatorio, la luz insistente del faro como símbolo de permanencia. En relación con esta segunda parte Rachel Blau du Plessis opina que, a manera de respuesta a "think of a table when you're not there", aquí se demuestra que las cosas: "depend for their meaning specifically on a feminine construction of subjective memory and coherence as well as on the hard female work of preservation and maintenance" (96). En este sentido, esta parte que ocupa el centro de la novela y que funciona a manera de un paréntesis temporal sería también una especie de paréntesis conceptual donde se muestra esa síntesis que Lily busca, ese equilibrio entre la autonomía individual y la experiencia de relación con los otros que va a encontrar más tarde.

En la última parte, mientras que Mr. Ramsey y sus hijos se dirigen finalmente al faro, Lily, inspirada esta vez no por la presencia sino por la ausencia, por el recuerdo de Mrs. Ramsey, debe enfrentarse de nuevo al problema de la creatividad: "Here she was again... drawn out of gossip, out of living, out of community with people into the presence of this formidable ancient enemy of hers -this other thing, this truth, this reality, which suddenly laid hands on her, emerged stark at the back of appearances and commanded her attention" (232).

Lily descubre que la realidad que quiere representar es de orden subjetivo y emocional más que intelectual, y que su fuente no es otra que Mrs. Ramsey, la "verdadera", aquella a quien finalmente pudo descubrir detrás de las apariencias. Lily busca esa otra realidad, y la revelación que tanto ha esperado surge del recuerdo de esta mujer: "Mrs. Ramsey making of the moment something permanent (as in another sphere Lily herself tried to make of the moment something permanent) - this was of the nature of a revelation. In the midst of chaos there was shape; this eternal passing and flowing... was struck into stability" (237).

¿No es acaso lo mismo, esa necesidad de darle forma al caos, de hacer del momento pasajero algo permanente gracias a la creación artística, de 
darle forma a la experiencia subjetiva, lo que persigue Virginia Woolf en esta novela? De ese universo confuso de voces interiores y conciencias aisladas, de esa cantidad de sensaciones dispersas, de esa multiplicidad de realidades, surge un objeto acabado que logra dar forma y sentido a las emociones personales. Es el descubrimiento de la propia voz lo que le permite a Lily darle forma y sentido a su percepción interior, pero esto lo logra, paradójicamente, gracias a un proceso de profundización, de inmersión casi, en el otro, fundamentalmente en la otra que es Mrs. Ramsey, objeto central de su cuadro (y objeto central de esta misma novela): "So in its attitudes, preparations, and achievements, Lily's art is much closer to the model Mrs. Ramsey had presented, despite Lily's rejection of some of the feminine social duties she encourages" (Blau du Plessis: 97). Es como si tanto Lily como la propia Woolf hubieran compartido a lo largo de la novela una experiencia equivalente: la de armar el rompecabezas del mundo interior de la propia experiencia para poder sacarlo a la luz del entendimiento, dándole una voz a ciertos personajes, particularmente a los femeninos, que de otra manera habrían permanecido en silencio.

Obras citadas

AUERBACH, Erich. 1979. Mimesis. México: FCE.

BlaU DU Plessis, Rachel. 1985. Writing Beyond the Ending. Bloomington: Universidad de Indiana.

Waugh, Patricia. 1992. Practising Postmodernism, Reading Modernism. Londres: Edward Arnold,

WOOLF, Virginia. 1996. To the Lighthouse. Londres: Penguin Books. 